\title{
Carmustine enhances the anticancer activity of selenite in androgen-independent prostate cancer cells
}

This article was published in the following Dove Press journal:

Cancer Management and Research

8 November 2012

Number of times this article has been viewed

\author{
Vijayalakshmi Thamilselvan \\ Mani Menon \\ Sivagnanam Thamilselvan \\ Vattikuti Urology Institute, Henry \\ Ford Health System, Detroit, MI, USA
}

\begin{abstract}
Apoptosis is one of the major mechanisms targeted in the development of therapies against various cancers, including prostate cancer. Resistance to chemotherapy poses a significant problem for the effective treatment of androgen-independent (hormone-refractory) prostate cancer. Although high concentrations of sodium selenite exert strong anticarcinogenic effects in several cell culture systems and animal models, the therapeutic potential of selenite in patients with advanced or metastatic prostate cancer is extremely limited by the genotoxicity of high-dose selenite. We examined the ability of nontoxic concentrations of selenite to promote apoptosis and inhibit proliferation in carmustine-sensitized androgen-independent human prostate cancer cells. Androgen-dependent LNCaP cells exhibited a significant decrease in cell viability when exposed to nontoxic concentrations of selenite, whereas androgen-independent PC-3 and DU145 cells showed a significant decrease in cell viability only at higher concentrations. Treatment of PC-3 cells with a combination of nontoxic selenite and carmustine resulted in greater increases in cytotoxicity, reactive oxygen species generation, growth inhibition, apoptosis, and DNA double-strand breaks, with concomitant decreases in DNA synthesis, glutathione, glutathione reductase, and antiapoptotic proteins. Combination treatment with carmustine and selenite triggered caspase-dependent apoptosis in PC-3 cells, which was not apparent when these cells were treated with selenite or carmustine alone. Genotoxicity in normal prostate epithelial cells was completely absent in the combination treatment of carmustine and selenite. In addition, carmustine decreased the induction of DNA double strand breaks by high-dose selenite in normal prostate epithelial cells. This is the first study to demonstrate that a nontoxic dose of selenite, in combination with carmustine, significantly induces apoptosis and growth inhibition in androgen-independent prostate cancer cells without causing undesirable genotoxicity in normal prostate epithelial cells, suggesting that this combination therapy may be a promising therapeutic approach in the treatment of patients with metastatic hormone-refractory prostate cancer.
\end{abstract}

Keywords: apoptosis, glutathione, glutathione reductase, oxidative stress, DNA damage, genotoxicity, combination therapy

\section{Introduction}

Prostate cancer is the second most common malignancy and the sixth leading cause of cancer-related mortality in men worldwide. ${ }^{1}$ The American Cancer Society has projected that the number of new cases of prostate cancer in the US will exceed 241,740 and about 28,170 prostate cancer deaths are anticipated in $2012 .^{2}$ Although most prostate cancers are initially androgen-dependent and respond well to androgen ablation therapy, they soon become androgen-independent, and their responses to therapy are transient, resulting in death due to the development of aggressive metastatic hormonerefractory disease. Although nonhormonal systemic chemotherapeutic regimens may
Correspondence: Sivagnanam

Thamilselvan

Department of Urology, Suite 2D-34, Henry Ford Health System, One Ford

Place, Detroit, MI 48202, USA

Tel +l 3138749104

Fax + I 3138746042

Email STHAMILI@HFHS.ORG 
thus represent another option for patients with androgenindependent prostate cancer (AIPC), AIPC usually exhibits resistance to chemotherapy and radiotherapy. However, while therapeutic options for patients with AIPC are limited due to the lack of evidence for long-term survival, current docetaxelbased chemotherapy can extend survival slightly, with a median survival rate of 10-19 months after diagnosis and treatment. ${ }^{3}$ Currently, there are no effective chemotherapeutic options for patients with AIPC. Therefore, there is an urgent need for anticancer drugs that can target multiple signaling pathways to trigger the apoptotic cascade in AIPC.

Generation of reactive oxygen species (ROS), including superoxides, hydrogen peroxide, hydroxyl radicals, and nitrogen oxide, is an inevitable event under aerobic conditions. Normally, the balance between generation and degradation of ROS is under delicate cellular control, and very low steadystate ROS concentrations are maintained. When this balance is destroyed, ROS affects carcinogenesis and cancer progression by causing oxidative damage to macromolecules, such as proteins, lipids, and DNA. It is postulated that such persistent oxidative stress present in cancer cells leads to cell proliferation rather than apoptosis. ${ }^{4,5}$ However, further increase in the levels of oxidative stress triggered by exogenous agents are more likely to cause apoptosis in cancer cells. ${ }^{6}$ Even though increased accumulation of ROS is required to trigger effective apoptosis in highly malignant cancer cells, built-in cellular defense mechanisms in metastatic cancer cells play a major role in protecting tumor cells against antineoplastic therapies. ${ }^{7}$ Therefore, regulating the intracellular redox state may represent an ideal strategy to sensitize cancer cells to anticancer therapy in a selective manner.

Given the lack of effective therapy for AIPC, selenite, an inorganic form of selenium, is of particular significance because administration of selenite exerts strong anticarcinogenic effects by increasing ROS levels in several cell culture systems and animal models. ${ }^{8}$ The prostate cancer chemoprevention trials, eg, the Selenium and Vitamin E Cancer Prevention Trial (SELECT), have clearly established that selenium in the form of L-selenomethionine (an organic form) does not prevent prostate cancer, ${ }^{9}$ indicating that the antitumor effects of selenium are dependent on its chemical form. Selenite has been shown to have chemopreventive effects against cancer when consumed at nutritional levels and anticarcinogenic potential at supranutritional doses, ie, nontoxic doses greater than those required to support the maximal expression of selenoenzymes. ${ }^{10}$ Normal selenite levels in serum or plasma were reported to range from 60 to $120 \mu \mathrm{g} / \mathrm{L}$, corresponding to 76 to $151 \mu \mathrm{g} / \mathrm{L}$ in whole blood, and the recommended daily allowance for selenium is $55 \mu \mathrm{g}$ /day for both men and women. ${ }^{11,12}$ A selenium intake of $400 \mu \mathrm{g}$ per day is considered a safe upper limit, with daily intake primarily from dietary supplementation and foods rich in selenium. ${ }^{12}$

At low concentrations, selenite can increase cell proliferation and suppress apoptosis, while higher concentrations decrease cell proliferation and cause apoptosis in several cancer cell lines and animal models, suggesting potential clinical applications. ${ }^{8} 10$ Earlier reports have shown that lower concentrations of selenite $(2.5 \mu \mathrm{M})$ effectively induce apoptosis in androgen-dependent prostate cancer cells, while higher concentrations of selenite $(>10 \mu \mathrm{M})$ are required to induce apoptosis in AIPC cells. ${ }^{13-15}$ In addition, studies have indicated that selenite $10 \mu \mathrm{M}$ exerts chemotherapeutic effects in liver hepatocellular carcinoma cells by inducing apoptosis; however, the same concentration also induces apoptosis in normal liver cells and mammary epithelial cells. ${ }^{16-19}$ Corcoran et al reported that high-dose dietary supplementation of inorganic selenium (3 ppm) inhibited progression of AIPC in a mouse xenograft model.$^{20}$ Earlier studies have shown that intraperitoneal administration of selenite $2 \mathrm{mg} / \mathrm{kg}$ significantly inhibited the growth of established LAPC-4 (androgen-dependent) xenograft tumors, but not PC-3 (androgen-independent) xenograft tumors. ${ }^{21}$ In mouse PC-3 and DU-145 xenograft models, administration of selenite $3 \mathrm{mg} / \mathrm{kg}$ for 49 days did not have growth inhibitory effects, but did induce DNA single-strand breaks in peripheral lymphocytes. ${ }^{22}$ These preclinical studies have shown that high doses of selenite have chemotherapeutic potential. However, selenite has not yet been evaluated in clinical studies of prostate cancer due to the occurrence of selenite-induced genotoxicity in normal cells. Thus, it is still unclear whether high-dose selenite is beneficial for patients with prostate cancer.

Although selenite is toxic to prostate cancer cells, its antitumor effects are overshadowed by its high-dose toxicity to normal cells, which poses a problem for its potential use in clinical studies. ${ }^{14}$ Therefore, precise modulation of redox levels may facilitate the selective killing of cancer cells without exerting significant toxicity in normal cells. The major objective of our study was to sensitize AIPC cells to apoptotic induction by employing a redox modulator to allow the effective targeting of AIPC cells by selenite at relatively low doses. This would constitute an antitumor effect of selenite that could be effectively translated to the clinical environment. Our treatment approach focused on modulating the redox environment of AIPC cells with carmustine and low 
doses of selenite. Selenite is known to increase the generation of ROS by catalytic oxidation of glutathione, whereas carmustine (1,3-bis(2-chloroethyl)-1-nitrosourea) is an alkylating chemotherapeutic agent that decomposes to form an alkylating moiety, which interacts with DNA to promote DNA cross-linking, and a carbamylating moiety associated with the inactivation of glutathione reductase, ${ }^{23}$ an enzyme that reduces glutathione disulfide to glutathione. The inactivation of glutathione reductase and the loss of glutathione were expected to overcome peroxide removal by glutathione peroxidase effectively.

Therefore, we hypothesize that induction of ROS by alteration of intracellular redox systems with combination of carmustine and a nontoxic dose of selenite can effectively induce highly metastatic, chemotherapy-resistant AIPC cells to undergo apoptosis and growth inhibition while sparing normal prostate epithelial cells from damage.

\section{Materials and methods Materials}

Roswell Park Memorial Institute (RPMI) 1640, Dulbecco's Modified Eagle Medium, and F-12K medium (Gibco-BRL Life Technologies Inc, Gaithersburg, MD); sodium selenite, $2^{\prime}, 7^{\prime}$-dichlorofluorescein diacetate, carmustine, and anti-actin antibodies (Sigma Chemical Co, St Louis, MO); assay kits for glutathione reductase (Cayman Chemical, Ann Arbor, MI); Cell Death Assay kit(Roche Diagnostics Corporation, Indianapolis, IN); bromodeoxyuridine (5-bromo-2-deoxyuridine, BrdU) proliferation assay kit (Calbiochem, La Jolla, CA); antibodies against poly (ADP-ribose) polymerase (PARP), Bcl-2, Mcl-1, and phospho-H2AX (Cell Signaling Technology, Danvers, MA); and MnTMPyP (1-methyl-4-pyridyl)porphyrin (EMD Chemicals, Gibbstown, NJ) were used in this study.

\section{Cell culture and treatment}

Prostate cancer cell lines (LNCaP, DU145, and PC-3) and normal prostate epithelial cell line (PZ-HPV-7), derived from epithelial cells of the peripheral zone of normal prostate tissue, were obtained from the American Type Culture Collection (Manassas, VA). PZ-HPV-7 cells were cultured in keratinocyte serum-free medium supplemented with $5 \mathrm{ng} / \mathrm{mL}$ human recombinant epidermal growth factor and $0.05 \mathrm{mg} / \mathrm{mL}$ bovine pituitary extract (Gibco). Prostate cancer cells were cultured in RPMI (LNCaP), Dulbecco's Modified Eagle Medium (DU145), or F-12K (PC-3) medium supplemented with 10\% fetal bovine serum, 100 units $/ \mathrm{mL}$ penicillin, and $100 \mathrm{~g} / \mathrm{mL}$ streptomycin, and were maintained in an atmosphere of $5 \%$ $\mathrm{CO}_{2}$ in a $37^{\circ} \mathrm{C}$ humidified incubator. Sodium selenite was added to the culture medium to achieve final concentrations of $0.5,1,1.5,2.5,5$, or $10 \mu \mathrm{M}$. Carmustine was dissolved in ethanol, and the final concentration of ethanol in the culture medium was kept at $0.1 \%(\mathrm{v} / \mathrm{v})$ in cells treated with carmustine. We selected carmustine concentrations of 10 and $20 \mu \mathrm{M}$ based on our concentration-dependent studies on cellular glutathione reductase levels. Cells were treated with carmustine $(10$ or $20 \mu \mathrm{M}) 30$ minutes prior to selenite treatment. Control cells were treated with $0.1 \%$ ethanol (vehicle). We considered $2.5 \mu \mathrm{M}$ selenite as a nontoxic dose, because this level did not affect cell viability or induce DNA double strand breaks in normal prostate epithelial cells, whereas a higher concentration $(5 \mu \mathrm{M})$ induced significant DNA double strand breaks (Figures 1A and 7).

\section{Cell viability and growth assays}

Cell viability and growth were determined by MTT (3-(4, 5-dimethylthiazol-2-yl)-2, 5-diphenyltetrazolium bromide) assay as described previously. ${ }^{24}$ Briefly, for cell viability assays, cells were seeded in 48-well plates at a density of $5 \times 10^{4}$ cells per well and allowed to grow for 48 hours. For growth assays, cells were seeded in 48 -well plates at a density of $3 \times 10^{4}$ cells per well and allowed to adhere for 24 hours. Cells were exposed to sodium selenite $(0,0.5$, $1,1.5,2,2.5,5$, or $10 \mu \mathrm{M})$ in the presence or absence of carmustine $(10$ or $20 \mu \mathrm{M})$. Cells treated with $0.1 \%$ ethanol for 24, 48, and 72 hours were used as controls. At the end of the experimental period, MTT $(5 \mathrm{mg} / \mathrm{mL}$ in phosphatebuffered saline; $20 \mu \mathrm{L}$ per well) was added to each well, and the cells were incubated for 4 hours at $37^{\circ} \mathrm{C}$. MTT was then removed, and dimethylsulfoxide was added to each well. Plates were agitated for 5 minutes to dissolve the crystals fully, and absorbance was measured at $550 \mathrm{~nm}$ using a spectrophotometer. The percentage of viable cells was calculated as follows: $\%$ viability $=$ absorbance of the experimental group/absorbance of the control group $\times 100$.

\section{DNA synthesis}

DNA synthesis was determined by immunoassay for quantification of BrdU incorporation into the newly synthesized DNA of actively proliferating cells using a BrdU cell proliferation assay kit (Calbiochem) as described previously. ${ }^{24}$ Cells $\left(2 \times 10^{3}\right)$ seeded in 96-well flat bottom plates were exposed to selenite $(0,1.5,2.5$, or $5 \mu \mathrm{M})$ in the presence or absence of carmustine ( 10 or $20 \mu \mathrm{M})$ for 24 hours. Cells treated with $0.1 \%$ ethanol were used as controls. BrdU was added, and the amount of BrdU incorporated was determined according to the manufacturer's instructions. 


\section{ROS measurement}

Intracellular ROS levels were determined by measuring the oxidative conversion of cell-permeable $2^{\prime}, 7^{\prime}$-dichlorofluorescein diacetate to fluorescent dichlorofluorescein in a fluorescence spectrophotometer. ${ }^{25}$ In brief, cells were treated with different concentrations of selenite with or without carmustine for 2 hours. The cells were incubated with $2^{\prime}, 7^{\prime}-$ dichlorofluorescein diacetate at a final concentration of $10 \mu \mathrm{M}$ for an additional 20 minutes at $37^{\circ} \mathrm{C}$. Dichlorofluorescein fluorescence, reflecting the concentration of ROS, was detected using a fluorescence spectrophotometer at $534 \mathrm{~nm}$ emission with an excitation wavelength of $488 \mathrm{~nm}$.

\section{Glutathione reductase activity}

Glutathione reductase activity was assayed spectrophotometrically by monitoring the oxidation of NADPH to NADP ${ }^{+}$ at $340 \mathrm{~nm}$ using an enzyme assay kit (Cayman Chemical).

\section{Determination of reduced glutathione}

Glutathione content was analyzed by a modified enzymatic recycling assay using 5-thio-2-nitrobenzoate to form a spectrophotometrically detectable product at $412 \mathrm{~nm} .{ }^{25}$

\section{Apoptosis}

Apoptosis was determined using the Cell Death Detection ELISA PLUS kit (Roche Applied Science, Indianapolis, IN) as described previously. ${ }^{26}$ Briefly, cells were treated with vehicle alone or different concentrations of selenite $(1-10 \mu \mathrm{M})$ in the presence or absence of carmustine $(10$ or $20 \mu \mathrm{M})$ for 24 hours. The assay is based on a quantitative sandwich enzyme immunoassay principle using mouse monoclonal antibodies directed against DNA and histones, which allows specific determination of mononucleosomes and oligonucleosomes in the cytoplasmic fraction of cell lysates. Nucleosome enrichment was quantified by determination of absorbance at $405 \mathrm{~nm}$.

In addition, we also assessed the potential involvement of ROS in selenite-induced and/or carmustine-induced apoptosis. For this experiment, the cells were treated with $20 \mu \mathrm{M}$ carmustine for 30 minutes and then incubated with $10 \mu \mathrm{M}$ of MnTMPyP, a synthetic superoxide dismutase mimic, along with selenite $(2.5-5 \mu \mathrm{M})$ for 24 hours. Apoptosis was then determined.

\section{Western blot analysis}

Cells were lysed in lysis buffer containing $10 \mathrm{mmol} / \mathrm{L}$ Tris (pH 7.4), $100 \mathrm{mmol} / \mathrm{L} \mathrm{NaCl}, 1 \mathrm{mmol} / \mathrm{L}$ ethylenediamine tetra-acetic acid, $1 \mathrm{mmol} / \mathrm{L}$ ethylene glycol tetra-acetic acid, $1 \mathrm{mmol} / \mathrm{L}$
$\mathrm{NaF}, 0.1 \%$ sodium dodecyl sulfate, $0.5 \%$ deoxycholate, $10 \%$ glycerol, $1 \%$ Triton X-100, $20 \mathrm{mmol} / \mathrm{L} \mathrm{Na}_{4} \mathrm{P}_{2} \mathrm{O}_{7}, 5 \mathrm{mg} /$ $\mathrm{mL}$ aprotinin, $5 \mathrm{mg} / \mathrm{mL}$ leupeptin, $2 \mathrm{mmol} / \mathrm{L} \mathrm{Na}_{3} \mathrm{VO}_{4}$, and $1 \mathrm{mmol} / \mathrm{L}$ phenylmethylsulfonyl fluoride. ${ }^{24}$ Equal amounts of protein were subjected to sodium dodecyl sulfate-polyacrylamide gel electrophoresis and transferred onto nitrocellulose membranes. The membranes were blocked in 5\% milk, incubated with primary antibodies directed against Bcl-2, Mcl-1, pH2AX, and cleaved PARP, and then incubated with horseradish peroxidase-conjugated secondary antibodies at room temperature. The blots were washed with Tris-buffered saline with $0.1 \%$ Tween-20, and immunoreactive bands visualized with an enhanced chemiluminescence Western blot detection kit (GE Healthcare Bio-Sciences, Piscataway, NJ) and analyzed using Kodak molecular imaging software, Carestream Health, Inc., Rochester, NY.

\section{Statistical analysis}

The Student's $t$-test for independent analysis was used to evaluate differences between treated and untreated cells. A $P$ value of less than 0.05 was considered to be statistically significant.

\section{Results \\ Effects of selenite on viability of normal prostate and cancer cells}

To investigate the cytotoxic effects of selenite, prostate cancer cells were exposed to increasing concentrations of selenite for 48 hours, and cell viability was measured using the MTT assay. Selenite significantly reduced the viability of LNCaP, DU145, and PC-3 cells in a concentration-dependent manner compared with their respective control cells ( $\mathrm{n}=4 ; P<0.05$; Figure 1A). A significant concentrationdependent decrease in cell viability occurred in LNCaP cells (androgen-dependent) at nontoxic concentrations of $1.0-2.5 \mu \mathrm{M}$ selenite. Treatment with $2.5 \mu \mathrm{M}$ selenite reduced $\mathrm{LNCaP}$ cell viability to $32 \% \pm 0.9 \%$, whereas cell viability was only reduced to $74 \% \pm 1 \%$ and $68 \% \pm 0.5 \%$ in androgen-independent PC-3 and DU145 cells, respectively. Treatment with $5 \mu \mathrm{M}$ selenite for 48 hours reduced viability to $52.0 \% \pm 2.8 \%, 46 \% \pm 2.2 \%$, and $12.0 \% \pm 1.2 \%$ in PC-3, DU145, and LNCaP cells, respectively. These viabilities were reduced further with higher concentrations of selenite; treatment with $10 \mu \mathrm{M}$ selenite for 48 hours reduced viability to $31.0 \% \pm 3.6 \%, 36 \% \pm 3.1 \%$, and $8.0 \% \pm 1.8 \%$ in PC-3, DU145, and LNCaP cells, respectively. Viability of normal prostate epithelial cells was unaffected by $0.5-5 \mu \mathrm{M}$ selenite $(98.2 \% \pm 1.8 \%$ at $2.5 \mu \mathrm{M}$ selenite; $92.5 \% \pm 3.1 \%$ 

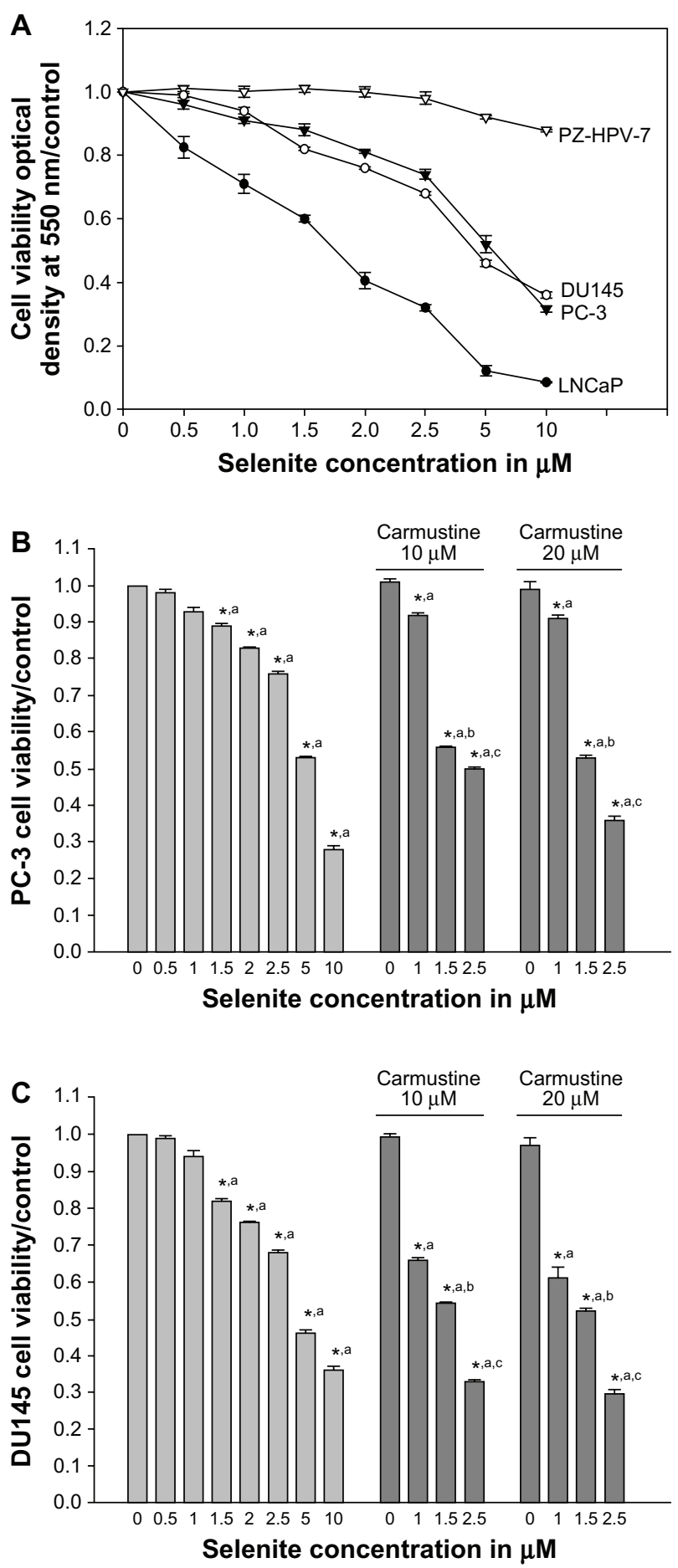

Figure I Nontoxic doses of selenite enhance cytotoxicity in PC-3 cells sensitized with carmustine. (A) Prostate cancer cells (LNCaP, DUI45, and PC-3) and normal prostate epithelial cells (PZ-HPV-7) were treated with different concentrations of selenite $(0.5-10 \mu \mathrm{M})$ for 48 hours. Cell viability was then determined as described in the Materials and methods section. Data are presented as the mean \pm standard deviation $(* P<0.05 ; n=4)$ and expressed as a percentage of viable cells. Data were normalized to the control. (B) PC-3 and (C) DUI45 cells were pretreated with 10 or $20 \mu \mathrm{M}$ carmustine for 30 minutes and then treated with the indicated concentrations of selenite $(0.5-10 \mu \mathrm{M})$ for 48 hours. Cell viability was then determined. The data are presented as the mean \pm standard deviation. ( $* P<0.05$; $n=3$ ) and expressed as the percentage of viable cells. Data are normalized to the control. Comparisons shown: (a) significant compared with vehicle-treated control; (b) significant compared with I.5 $\mu \mathrm{M}$ selenite-treated cells; (c) significant compared with $2.5 \mu \mathrm{M}$-selenite-treated cells. at $5 \mu \mathrm{M}$ selenite). However, $10 \mu \mathrm{M}$ selenite reduced the viability of normal prostate epithelial cells to $87 \% \pm 2.3 \%$. Our results showed that androgen-dependent prostate cancer cells are sensitive to a low concentration of selenite $(2.5 \mu \mathrm{M})$, whereas AIPC cells are sensitive to high concentrations of selenite $(>5 \mu \mathrm{M})$.

\section{Carmustine sensitizes AIPC cells to low- dose selenite-induced cytotoxicity}

Because PC-3 cells were highly resistant to nontoxic concentrations of selenite $(1.5$ and $2.5 \mu \mathrm{M})$ compared with $\mathrm{LNCaP}$ cells, we attempted to sensitize PC-3 cells to respond to low-dose selenite with carmustine. Decreased cell viability occurred in PC-3 cells treated with selenite in a concentrationdependent manner $(0.5-10.0 \mu \mathrm{M})$. Control cells treated with vehicle $(0.1 \%$ ethanol) did not show any changes in cell viability after 48 hours. Similarly, treatment with 10 or $20 \mu \mathrm{M}$ carmustine showed no changes in cell viability. While only minimal changes in cell viability were observed on treatment with 1.5 or $2.5 \mu \mathrm{M}$ selenite, the presence of 10 or $20 \mu \mathrm{M}$ carmustine dramatically decreased cell viability in PC-3 cells treated with 1.5 or $2.5 \mu \mathrm{M}$ selenite (Figure $1 \mathrm{~B}$ ). Similar results were also seen in DU145 cells treated with carmustine with or without 1.5 or $2.5 \mu \mathrm{M}$ selenite (Figure 1C). Because $10 \mu \mathrm{M}$ selenite exerted greater toxic effects against PC-3 cells, which are highly metastatic and resistant to chemotherapy, further studies were carried out in PC-3 cells.

\section{Selenite and carmustine enhance growth inhibition and inhibit DNA synthesis in PC-3 cells}

The growth inhibitory effects of selenite in combination with carmustine were evaluated in PC-3 cells. PC-3 cells were exposed to different concentrations of selenite $(0.5,1,1.5,2.5$, or $5 \mu \mathrm{M}$ ) in the presence or absence of 10 or $20 \mu \mathrm{M}$ carmustine for 96 hours. Treatment with selenite suppressed PC-3 cell growth in a concentration-dependent manner (Figure 2A), and 10 or $20 \mu \mathrm{M}$ carmustine caused only minimal changes in PC-3 cell growth. Treatment with selenite alone at a concentration of $2.5 \mu \mathrm{M}$ suppressed cell growth by $31.9 \% \pm 1.1 \%$; however, in the presence of 10 and $20 \mu \mathrm{M}$ carmustine, $2.5 \mu \mathrm{M}$ selenite significantly suppressed cell growth by $65.0 \% \pm 2.7 \%$ and $79.0 \% \pm 3.7 \%$, respectively.

While $1.5 \mu \mathrm{M}$ selenite did not inhibit DNA synthesis, significant inhibition of DNA synthesis was observed at $2.5 \mu \mathrm{M}$ selenite when compared with the vehicle-treated control ( $\mathrm{n}=3 ; P<0.05$; Figure $2 \mathrm{~B}$ ). As expected, $5 \mu \mathrm{M}$ 

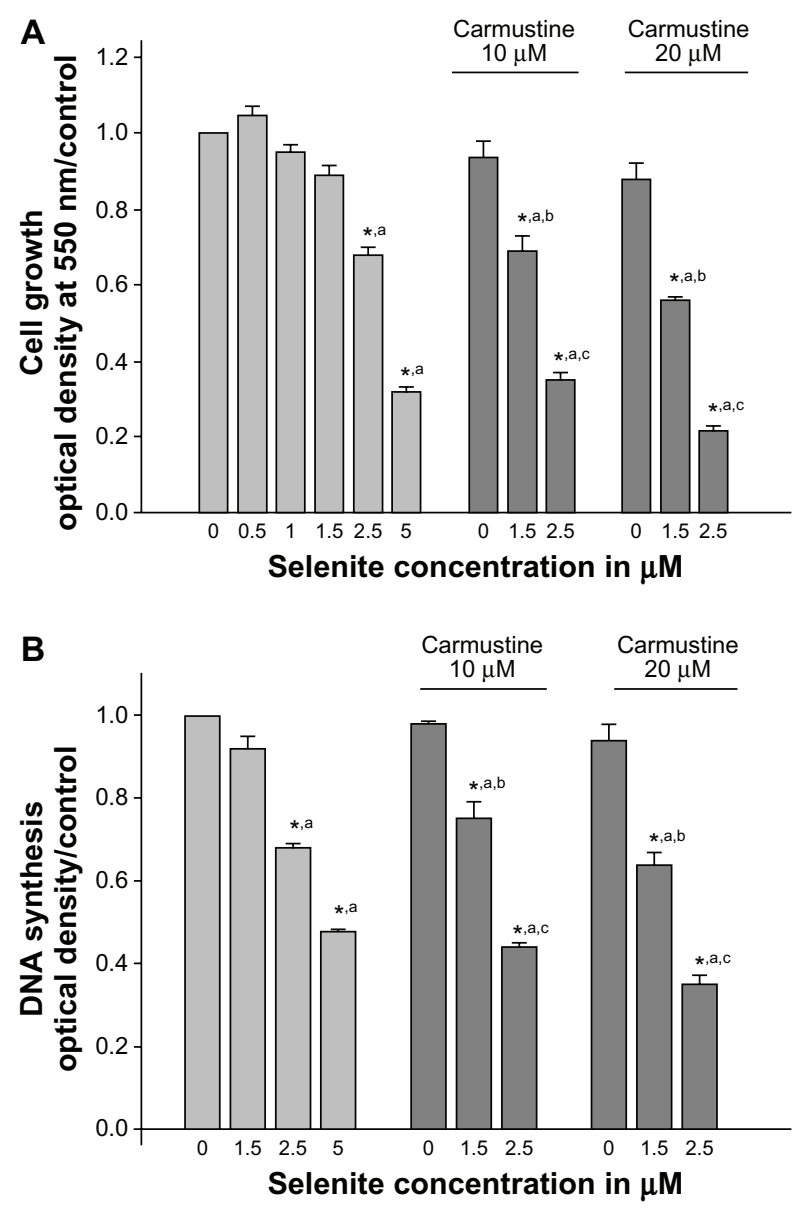

Figure 2 Nontoxic doses of selenite enhance growth inhibition and inhibit DNA synthesis in PC-3 cells sensitized with carmustine. PC-3 cells were pretreated with 10 or $20 \mu \mathrm{M}$ carmustine for 30 minutes and then treated with different concentrations of selenite $(0.5-5 \mu \mathrm{M})$ for 96 hours. (A) Cell growth and (B) DNA synthesis were then determined as described in the Materials and methods section. The data are presented as the mean \pm standard deviation. $(* P<0.05$; $\mathrm{n}=3$ ) and expressed as optical density at $550 \mathrm{~nm}$ for cell growth; optical density at $405 \mathrm{~nm}$ for DNA synthesis. Data are normalized to the control. Comparisons shown: (a) significant compared with control; (b) significant compared with I.5 $\mu \mathrm{M}$ selenite-treated cells; (c) significant compared with $2.5 \mu \mathrm{M}$ selenite-treated cells.

selenite also inhibited DNA synthesis. Additionally, strong concentration-dependent inhibition of DNA synthesis was noted with combination of selenite and carmustine treatment. In PC-3 cells sensitized with $20 \mu \mathrm{M}$ carmustine, treatment with 1.5 or $2.5 \mu \mathrm{M}$ selenite resulted in a $36.2 \% \pm 1.6 \%$ or a $65.0 \% \pm 3.7 \%$ reduction in DNA synthesis, respectively (Figure 2B). These data suggest that nontoxic selenite concentrations are potently cytotoxic as well as antiproliferative against AIPC cells sensitized with carmustine.

\section{Effects of selenite on cellular glutathione and glutathione reductase in carmustine- sensitized PC-3 cells}

Several studies have shown that glutathione is essential for cell survival; depletion of glutathione promotes apoptosis, and increased glutathione reductase activity has been associated with resistance to cancer therapy. ${ }^{27}$ Thus, we measured changes in cellular glutathione and glutathione reductase activity in PC-3 cells treated with low-dose selenite in the presence or absence of carmustine. PC-3 cells treated with carmustine for 6 hours exhibited a significant dose-dependent decrease in glutathione reductase activity (Figure 3A). Indeed, $10 \mu \mathrm{M}, 20 \mu \mathrm{M}$, and $40 \mu \mathrm{M}$ selenite decreased glutathione reductase activity by $30 \%, 50 \%$, and $70 \%$, respectively.

Cellular glutathione levels were determined in PC-3 cells after pretreatment with $20 \mu \mathrm{M}$ carmustine and treatment with $2.5 \mu \mathrm{M}$ selenite for different times $(6,12$, and 24 hours; Figure 3B). Twenty micromolar carmustine alone significantly decreased PC-3 cellular glutathione levels in a timedependent manner. However, addition of $2.5 \mu \mathrm{M}$ selenite to $20 \mu \mathrm{M}$ carmustine-sensitized PC-3 cells resulted in a dramatic decrease in cellular glutathione levels in a timedependent manner, as compared with treatment with $2.5 \mu \mathrm{M}$ selenite alone.

Next, we determined glutathione reductase activity in PC-3 cells pretreated with 10 and $20 \mu \mathrm{M}$ carmustine followed by treatment with 2.5 or $5 \mu \mathrm{M}$ selenite (Figure $3 \mathrm{C}$ ). Selenite caused a concentration-dependent increase in glutathione reductase activity. In the presence of $20 \mu \mathrm{M}$ carmustine, $2.5 \mu \mathrm{M}$ selenite significantly decreased glutathione reductase activity compared with treatment consisting of $2.5 \mu \mathrm{M}$ selenite alone. Overall, our data demonstrated that carmustine significantly decreased glutathione reductase activity and decreased glutathione levels, while selenite treatment alone significantly increased glutathione reductase activity and decreased glutathione levels. However, the combination treatment of nontoxic selenite $(2.5 \mu \mathrm{M})$ and $20 \mu \mathrm{M}$ carmustine significantly decreased both glutathione reductase activity and glutathione levels, increasing the vulnerability of cancer cells to oxidative stress.

\section{Effects of nontoxic selenite levels on ROS production in carmustine- sensitized PC-3 cells}

We further examined whether inhibition of glutathione reductase by carmustine and utilization of glutathione by selenite were accompanied by an increase in ROS production. Cellular generation of ROS was measured using H2DCF-DA, which converts to a fluorescent molecule after intracellular oxidation (Figure 4). PC-3 cells treated with either vehicle ( $0.1 \%$ ethanol), $20 \mu \mathrm{M}$ carmustine alone, or selenite ( 1.5 or $2.5 \mu \mathrm{M}$ ) alone did not exhibit any changes in intracellular 


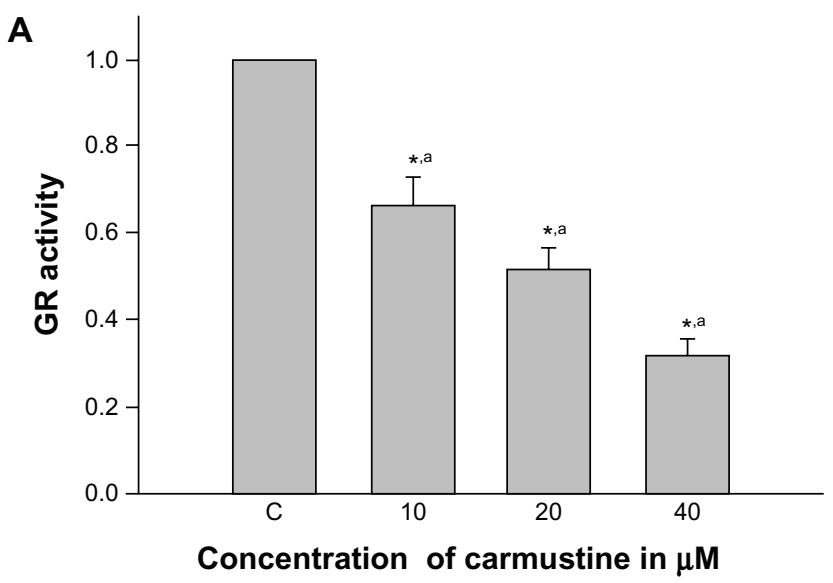

B

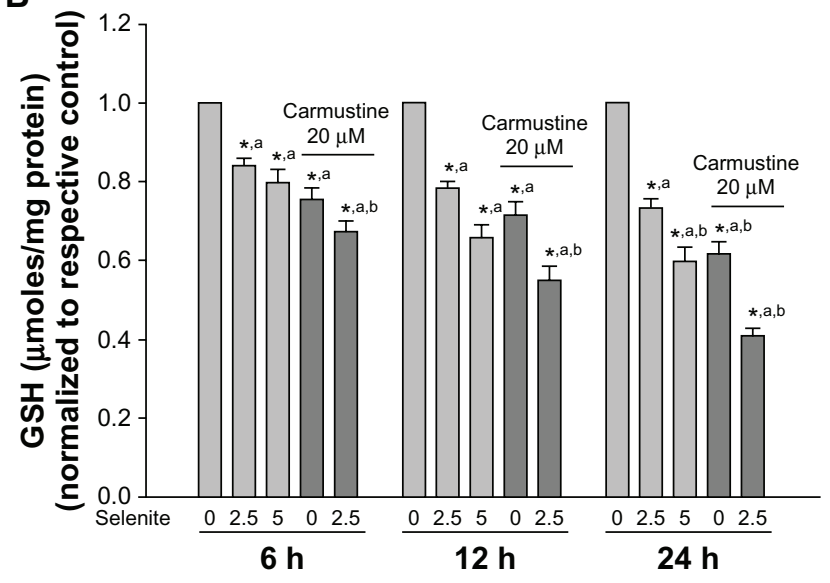

C

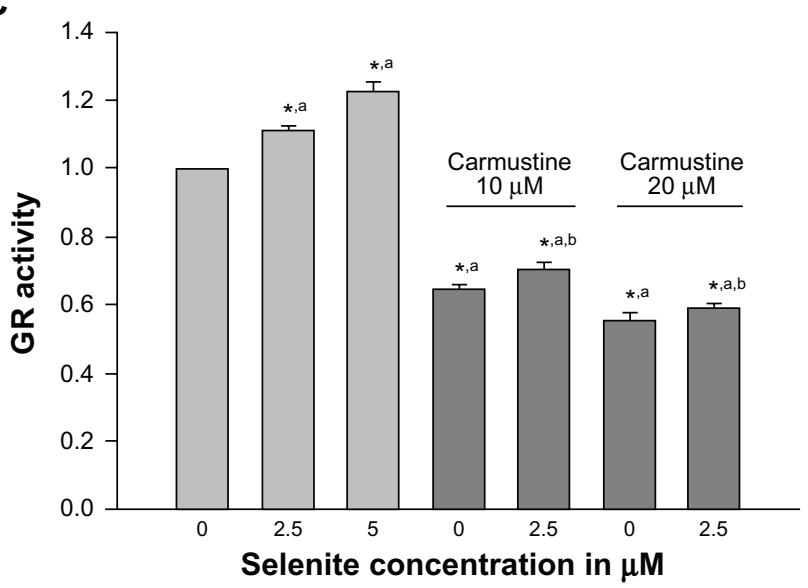

Figure 3 Nontoxic doses of selenite decrease glutathione reductase and glutathione in PC-3 cells sensitized with carmustine. (A) PC-3 cells were treated with the indicated concentrations of carmustine $(10-40 \mu \mathrm{M})$ for 6 hours. Glutathione reductase activity was then measured as described in the Materials and methods section. Each assay was performed in duplicate. The data are presented as the mean \pm standard deviation $(* P<0.05 ; n=3)$ and expressed as nanomoles of NADPH oxidized per minute per milligram of protein. Data are normalized to the control. Comparisons shown: (a) significant compared with vehicle-treated control. (B) PC-3 cells were pretreated with 20 $\mu \mathrm{M}$ carmustine for 30 minutes and then treated with the indicated concentrations of selenite $(2.5-5 \mu \mathrm{M})$ for 6,12 , and 24 hours. Glutathione levels were then determined as described in the Materials and methods section. Data are presented as the mean \pm standard deviation $(* P<0.05 ; n=3)$ and expressed as $\mu$ moles/mg protein. Data are normalized to the control. Comparisons shown: (a) significant compared with control; (b) significant compared with $2.5 \mu \mathrm{M}$ selenite-treated cells. (C) PC-3 cells were pretreated with 10 or $20 \mu \mathrm{M}$ carmustine for 30 minutes and then treated with the indicated concentrations of selenite (2.5-5 $\mu \mathrm{M})$ for 6 hours. Glutathione reductase activity was determined as described in the Materials and methods section. The data are presented as the mean \pm standard deviation $(* P<0.05 ; \mathrm{n}=3)$ and expressed as nanomoles of NADPH oxidized per minute per milligram of protein. Data are normalized to the control. Comparisons shown: (a) significant compared with control; (b) significant compared with $2.5 \mu \mathrm{M}$ selenite-treated cells.

Abbreviations: GSH, glutathione; GR, glutathione reductase.

ROS levels. However, when carmustine-sensitized PC-3 cells were treated with $2.5 \mu \mathrm{M}$ selenite, ROS generation was dramatically increased; these data correlated very well with decreased glutathione reductase activity and decreased glutathione in PC-3 cells treated with the combination of $20 \mu \mathrm{M}$ carmustine and $2.5 \mu \mathrm{M}$ selenite.

\section{Low-dose selenite induced apoptosis in carmustine-sensitized PC-3 cells via oxidative stress}

Because ROS can either promote cell survival or cell death depending on the type of cellular stress, we further investigated whether combined treatment with carmustine and selenite could induce apoptosis in PC-3 cells using an enzyme-linked immunosorbent assay method that measures histone-associated oligonucleotide formation (Figure 5A). Selenite treatment significantly increased apoptosis in PC-3 cells in a concentration-dependent manner. Apoptosis induction was minimal in PC-3 cells treated at $2.5 \mu \mathrm{M}$ selenite and significantly increased at $5 \mu \mathrm{M}$ selenite. Twenty micromolar carmustine alone did not induce apoptosis in PC-3 cells. In contrast, $2.5 \mu \mathrm{M}$ selenite triggered an increase in apoptosis from 1.6-fold to 4-fold in carmustine-sensitized PC-3 cells.

Given that combined treatment with carmustine and selenite enhanced apoptosis in PC-3 cells, we tested whether this increase was due to induction of ROS using MnTMPyP, an MnSOD mimetic agent. Apoptosis was significantly 


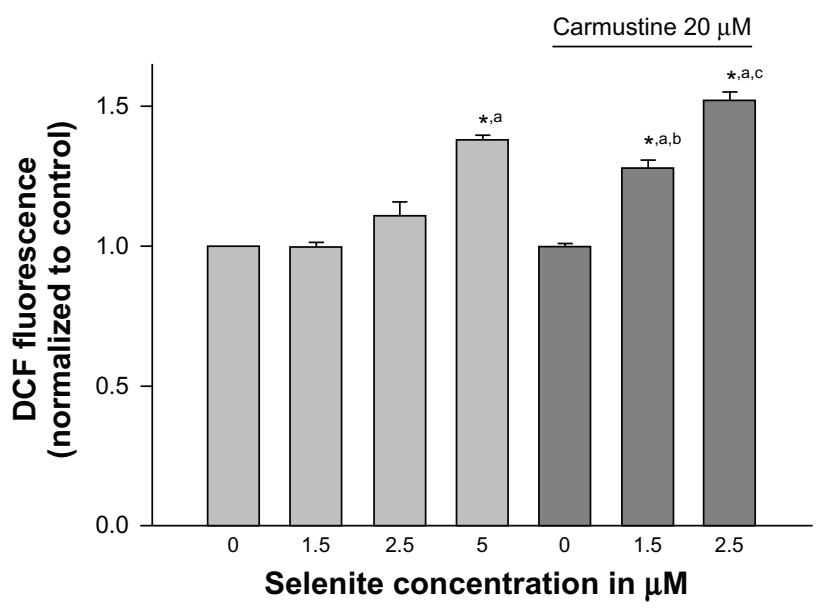

Figure 4 Nontoxic doses of selenite enhance generation of reactive oxygen species in PC-3 cells sensitized with carmustine. PC-3 cells were pretreated with 10 or $20 \mu \mathrm{M}$ carmustine for 30 minutes and then treated with the indicated concentration of selenite $(1.5-5 \mu \mathrm{M})$ for 2 hours. Generation of reactive oxygen species was then measured as described in the Materials and methods section. The data are presented as the mean \pm standard deviation $(* P<0.05$; $\mathrm{n}=3$ ) and expressed as relative fluorescence (\%). Data are normalized to the control. Comparisons shown: (a) significant compared with control; (b) significant compared with I.5 $\mu \mathrm{M}$ selenite-treated cells; (c) significant compared with $2.5 \mu \mathrm{M}$ selenite-treated cells.

Abbreviation: DCF, Dichlorofluorescein.

augmented in carmustine-sensitized PC-3 cells following treatment with $2.5 \mu \mathrm{M}$ selenite (Figure 5B). Treatment with MnTMPyP prevented apoptosis in PC-3 cells treated with $2.5 \mu \mathrm{M}$ selenite alone and in combination with $20 \mu \mathrm{M}$ carmustine. These findings clearly demonstrated that combination treatment with selenite and carmustine causes apoptosis via increased ROS generation.

\section{Effects of selenite and carmustine on $\mathrm{Bcl}-2$ family proteins, DNA double- strand breaks, and PARP cleavage in PC-3 cells}

Because Bcl-2 and Mcl-1 are members of the Bcl-2 family, which plays a key role in the regulation of apoptosis, we used Western blotting to analyze Bcl-2 and Mcl-1 expression in PC-3 cells pretreated with 10 or $20 \mu \mathrm{M}$ carmustine and then treated with 1.5-2.5 $\mu \mathrm{M}$ selenite (Figures $6 \mathrm{~A}$ and B). Data from densitometric analysis clearly indicated that selenite-treated PC-3 cells had significant decreases in Bcl-2 and Mcl-1 protein expression in a concentration-dependent manner. Carmustine 10 or $20 \mu \mathrm{M}$ also significantly decreased Bcl-2 and Mcl-1 protein expression. However, combined treatment with $2.5 \mu \mathrm{M}$ selenite and $20 \mu \mathrm{M}$ carmustine dramatically reduced Bcl-2 and Mcl-1 expression, correlating with increased apoptosis.

In addition, DNA double-strand break formation was examined by analyzing phospho-H2AX protein expression (Figure 6C). Phosphorylation of H2AX, an early
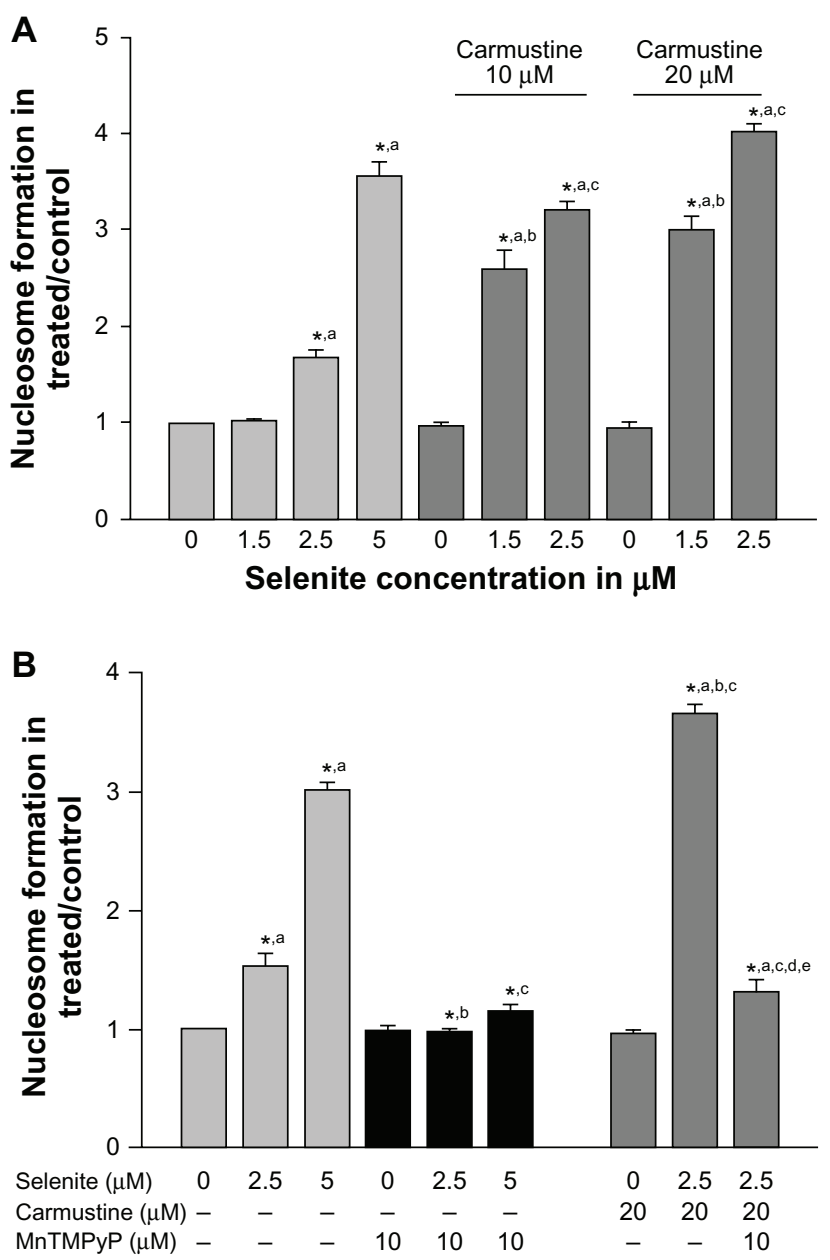

Figure 5 Nontoxic doses of selenite enhance apoptosis in PC-3 cells sensitized with carmustine, and this enhancement is mediated through oxidative stress. (A) PC-3 cells were pretreated with 10 or $20 \mu \mathrm{M}$ carmustine for 30 minutes and then treated with the indicated concentrations of selenite $(I .5-5 \mu \mathrm{M})$ for 24 hours. Apoptosis was then determined by enzyme-linked immunosorbent assay as described in the Materials and methods section. The data are presented as the mean \pm standard deviation ( $* P<0.05 ; \mathrm{n}=3$ ) and expressed as optical density at $405 \mathrm{~nm}$. Data are normalized to the control. Comparisons shown: (a) significant compared with control; (b) significant compared with $1.5 \mu \mathrm{M}$ selenite-treated cells; (c) significant compared with $2.5 \mu \mathrm{M}$ selenite-treated cells. (B) PC-3 cells were pretreated with $20 \mu \mathrm{M}$ carmustine for 30 minutes and then treated with $10 \mu \mathrm{M}$ MnTMPyP along with 2.5 or $5 \mu \mathrm{M}$ selenite for 24 hours. Apoptosis was then determined as described in the Materials and methods section. The data are presented as the mean \pm standard deviation ( $* P<0.05 ; \mathrm{n}=3$ ) and expressed as optical density at $405 \mathrm{~nm}$. Data are normalized to the control. Comparisons shown: (a) significant compared with the respective control; (b) significant compared with $2.5 \mu \mathrm{M}$ selenite-treated cells; (c) significant compared with $5 \mu \mathrm{M}$ selenite-treated cells; (d) significant compared with carmustine-treated cells; (e) significant compared with carmustine-treated and selenite-treated cells.

response to DNA double-strand breaks, was increased in PC-3 cells after 24 hours of exposure to $2.5 \mu \mathrm{M}$ selenite and was greatly enhanced after pretreatment with $20 \mu \mathrm{M}$ carmustine. As expected, high-dose selenite alone markedly increased phospho-H2AX in PC-3 cells. Overall, in the presence of $20 \mu \mathrm{M}$ carmustine, nontoxic concentrations of selenite induced increased apoptosis in androgen-independent PC-3 cells. 
A
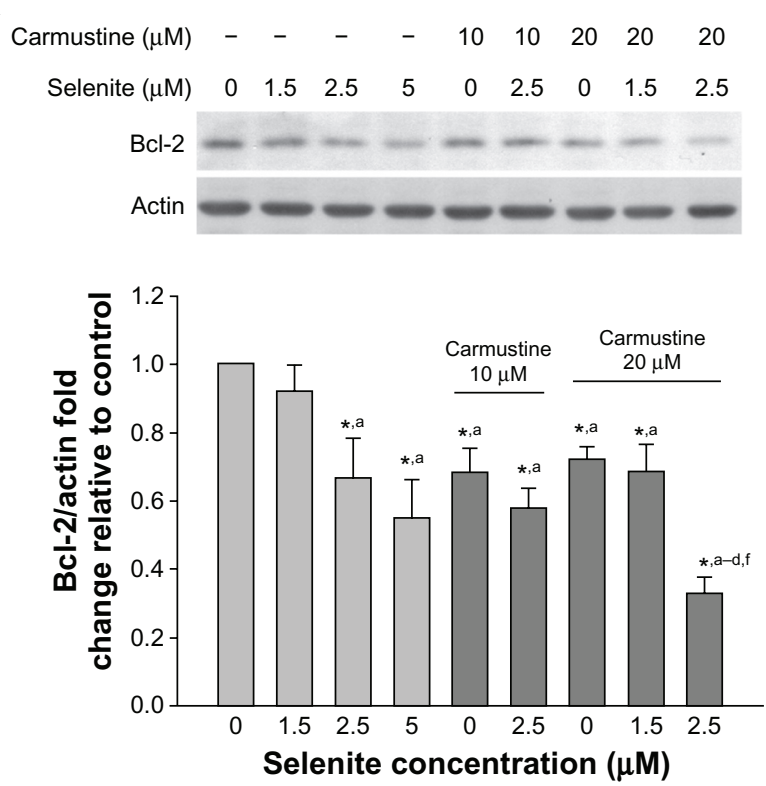

C

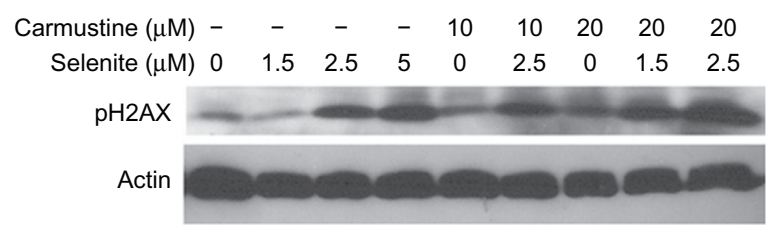

B
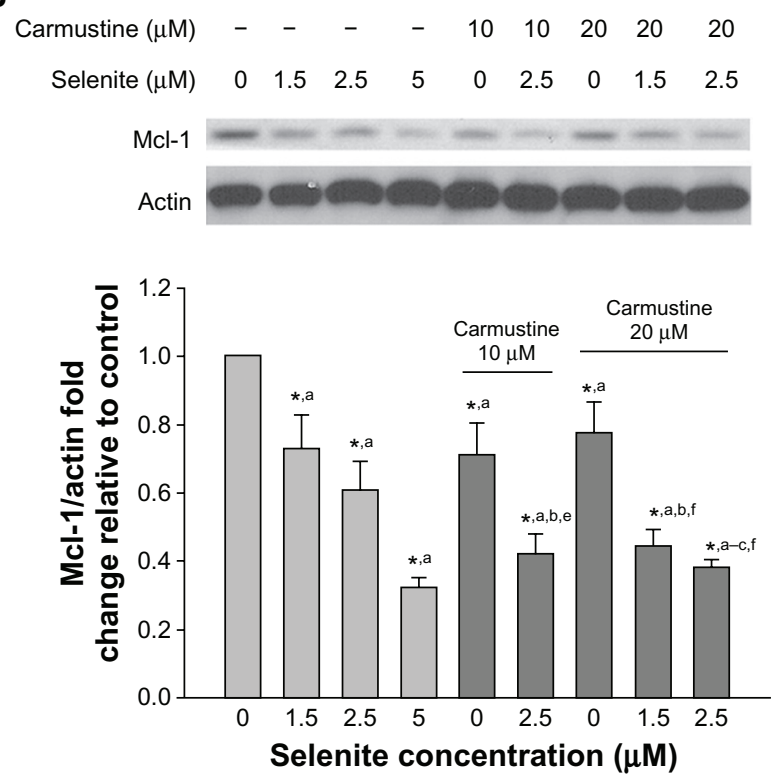

D
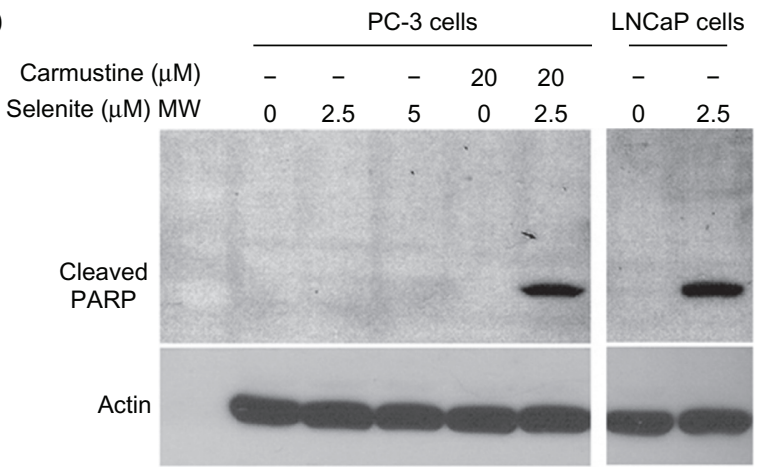

Figure 6 Nontoxic doses of selenite decrease the expression of antiapoptotic proteins, triggered PARP cleavage, and induced DNA double-strand breaks in PC-3 cells sensitized with carmustine. Prostate cancer cells were pretreated with 10 or $20 \mu \mathrm{M}$ carmustine for 30 minutes and then treated with the indicated concentrations of selenite $(\mathrm{I} .5-5 \mu \mathrm{M})$ for 24 hours. Cell lysates were prepared as described in the Materials and methods section. (A) Bcl-2 and (B) Mcl-I protein expression were determined by Western blot analysis in PC-3 cells. A typical Western blot from I of 3 experiments is shown. Densitometric analysis was performed on samples to evaluate the levels of Bcl2 and $\mathrm{Mcl}-\mathrm{I}$ protein expression in a quantitative manner. Graph represents the ratio of Bcl-2 or Mcl-I protein expression over $\beta$-actin (bottom panel). Data are normalized to control. Comparisons shown: (a) significant compared with control; (b) significant compared with I.5 $\mu \mathrm{M}$ selenite-treated cells; (c) significant compared with $2.5 \mu \mathrm{M}$ selenite-treated cells; (d) significant compared with $5.0 \mu \mathrm{M}$ selenite-treated cells; (e) significant compared with $10 \mu \mathrm{M}$ carmustine-treated cells; and (f) significant compared with $20 \mu \mathrm{M}$ carmustine-treated cells. (C) Phospho-H2AX (a marker of DNA double-strand breaks) was determined by Western blot analysis in PC-3 cells as described in the Materials and methods section. The blots shown are representative of three separate experiments. $\beta$-actin was used as a loading control. (D) PARP protein expression was determined by Western blot analysis in PC-3 and LNCaP cells as described in the Materials and methods section. The blots shown are representative of three separate experiments. $\beta$-actin was used as a loading control.

Abbreviation: $\mathrm{MW}$, molecular weight.

PARP is a nuclear enzyme involved in DNA repair and is a substrate for caspase-3 cleavage during apoptosis. Therefore, we examined the effects of selenite and selenite plus carmustine on PARP cleavage in PC-3 cells (Figure 6D). Treatment of androgen-dependent $\mathrm{LNCaP}$ cells with $2.5 \mu \mathrm{M}$ selenite caused significant cleavage of PARP, as revealed by generation of the $89 \mathrm{kDa}$ fragment, indicating that these cells were highly sensitive to low selenite concentrations. However, the same concentration of selenite in androgen-independent PC-3 cells did not cause PARP cleavage, indicating that these cells were highly resistant to apoptosis. In fact, PARP cleavage was not detectable in PC-3 cells even after exposure to high-dose selenite $(5 \mu \mathrm{M})$. Similarly, $20 \mu \mathrm{M}$ carmustine alone did not result in PARP cleavage in PC-3 cells. However, treatment of PC-3 cells with a nontoxic concentration of selenite $(2.5 \mu \mathrm{M})$ in the presence of $20 \mu \mathrm{M}$ carmustine caused significant PARP cleavage. These data strongly indicate that the combination of nontoxic selenite $(2.5 \mu \mathrm{M})$ and carmustine $(20 \mu \mathrm{M})$ induced PARP cleavage during the execution phase of apoptosis, confirming that sensitizing androgen-independent PC-3 cells with carmustine allowed nontoxic doses of selenite to exert a dramatic effect on apoptosis. 

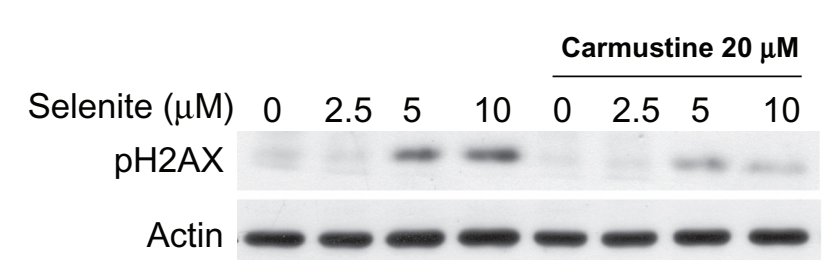

Figure 7 Absence of genotoxicity in normal prostate epithelial cells treated with a combination of nontoxic doses of selenite and carmustine. PZ-HPV-7 cells were pretreated with $20 \mu \mathrm{M}$ carmustine for 30 minutes and then treated with the indicated concentrations of selenite $(2.5-10 \mu \mathrm{M})$ for 24 hours. The expression of phospho$\mathrm{H} 2 \mathrm{AX}$ protein, a marker of DNA double-strand breaks, was then determined by Western blot analysis as described in the Materials and methods section. The blots shown are representative of three separate experiments. $\beta$-actin was used as a loading control.

\section{Combination treatment prevented genotoxicity in normal prostate epithelial cells}

Because selenite has been shown to induce genotoxicity, we assessed the effects of combination treatment with $20 \mu \mathrm{M}$ carmustine and $2.5 \mu \mathrm{M}$ selenite on DNA double-strand breaks in normal prostate epithelial cells. DNA double-strand breaks (phospho-H2AX) are an indicator of genotoxicity, and repair of these breaks is more difficult than that of other types of DNA damage. Given that combination treatment with $2.5 \mu \mathrm{M}$ selenite and $20 \mu \mathrm{M}$ carmustine significantly increased phospho-H2AX expression in androgen-independent PC-3 cells, we assessed whether the same combination treatment had any differential effects on normal prostate epithelial cells. As shown in Figure 7, normal prostate epithelial cells were unaffected by treatment with either $2.5 \mu \mathrm{M}$ selenite alone or a combination of $2.5 \mu \mathrm{M}$ selenite and $20 \mu \mathrm{M}$ carmustine. As expected, treatment with high-dose selenite $(5.0-10.0 \mu \mathrm{M})$ resulted in a significant increase in phospho-H2AX expression in normal prostate epithelial cells. However, carmustine sensitization significantly reduced induction of genotoxicity by high-dose selenite.

\section{Discussion}

Although the antitumor efficacy of selenite has been explored since 1986 in preclinical and cell culture models, ${ }^{28}$ the concept has not been applied to humans due to the toxic nature of high-dose selenite. To our knowledge, we were the first to demonstrate that exposure of carmustine-sensitized AIPC cells to nontoxic concentrations of selenite induced a substantial increase in apoptosis and growth inhibition without damaging normal cells, suggesting that this combined therapy of carmustine and selenite may have potential as a chemotherapy for AIPC.
The major findings of our studies are as follows:

- selenite induced concentration-dependent cytotoxicity in androgen-dependent and androgen-independent prostate cancer cells

- viability of normal prostate epithelial cells were affected by $10 \mu \mathrm{M}$ selenite

- LNCaP cells showed cytotoxicity to selenite at $1.5 \mu \mathrm{M}$, whereas PC-3 and DU145 cells showed significant toxicity only at $5 \mu \mathrm{M}$ concentration or higher

- selenite increased ROS generation in a concentrationdependent manner in PC-3 cells

- selenite decreased glutathione levels and increased glutathione reductase activity in a concentration-dependent and time-dependent manner in PC-3 cells.

- treatment of carmustine-sensitized PC-3 cells with selenite at a nontoxic concentration of $2.5 \mu \mathrm{M}$ induced a greater increase in ROS generation, PARP cleavage, phospho-H2AX expression, growth inhibition, and apoptosis, and caused additional decreases in DNA synthesis, glutathione, glutathione reductase activity, and $\mathrm{Bcl}-2$ and Mcl-1 protein expression.

- phospho-H2AX, a marker of double-stranded breaks, was not observed in normal prostate epithelial cells treated with $2.5 \mu \mathrm{M}$ selenite alone or with the combination of $2.5 \mu \mathrm{M}$ selenite and $20 \mu \mathrm{M}$ carmustine.

- pretreatment with carmustine significantly reduced the induction of phospho-H2AX by high-dose selenite in normal prostate epithelial cells.

- treatment with MnTMPyp in the presence or absence of $20 \mu \mathrm{M}$ carmustine and $2.5 \mu \mathrm{M}$ selenite significantly inhibited apoptosis, suggesting that ROS plays an important role in induction of apoptosis in response to combination treatment with carmustine and selenite.

Increasing evidence indicates that selenite exerts its anticancer effects via pro-oxidant activity. Selenite is capable of inhibiting growth and inducing apoptosis in a number of human cancer cell lines tested in vitro, including androgen-dependent LNCaP cells and androgen-independent PC-3 prostate cancer cells. ${ }^{29,30}$ Studies have shown that ROS formation and oxidative stress are causally related to the induction of apoptosis in selenite-treated cancer cells. ${ }^{31}$ The findings from our study indicate that induction of apoptosis by a combination of $2.5 \mu \mathrm{M}$ selenite and $20 \mu \mathrm{M}$ carmustine was inhibited by addition of a superoxide dismutase mimetic, further supporting the existence of a causal role for superoxide in cell death. Consistent with our results, studies by Zhong et al have shown that overexpression of MnSOD or treatment with MnTMPyP protects prostate cancer cells against the cytotoxic effects of selenite..$^{32}$ 
Selenite requires glutathione for its metabolism and to mediate its antitumor effect via ROS generation. Selenite increases ROS accumulation by reacting with glutathione to form selenodiglutathione; this compound is reduced to hydrogen selenide via a number of intermediate steps. Hydrogen selenide is then oxidized into superoxide radicals, hydrogen peroxide, and elemental selenium, resulting in oxidative damage and cell death. ${ }^{33}$ Selenodiglutathione, produced metabolically from selenite, has been shown to inhibit protein synthesis and increase apoptosis. ${ }^{34}$ However, it is not clear why selenite sensitivity and glutathione levels are not correlated in malignant cells. High intracellular glutathione in malignant cells has been reported to facilitate resistance to several chemotherapy drugs, and glutathione depletion has been shown to sensitize some cancer cell lines to selenite. ${ }^{35,36}$ Studies have shown that glutathione depletion is an attractive strategy in tumors exhibiting high glutathione content, because glutathione depletion reverses resistance to alkylating agents such as carmustine. ${ }^{37,38}$ Consistent with our findings, others have shown that treatment of tumor cells with buthionine sulfoximine increases their sensitivity to numerous bifunctional agents, including m-DDP, melphalan, and chloroethylnitrosoureas. ${ }^{39}$ Moreover, induction of glutathione-metabolizing enzymes during detoxification has been implicated as an adaptive mechanism to overcome oxidative stress. In animal models, high dietary selenite increases both glutathione and glutathione disulfide, with a decreased glutathione to glutathione disulfide ratio along with increased glutathione reductase and glucose-6-phosphate dehydrogenase activities as adaptive responses to selenite-induced glutathione oxidation. ${ }^{40,41}$ Interestingly, our study indicated that combination treatment with $2.5 \mu \mathrm{M}$ selenite and $20 \mu \mathrm{M}$ carmustine led to decreased glutathione reductase activity and glutathione levels in PC-3 cells, which could in turn produce significantly higher antitumor or apoptotic effects.

Although antioxidant enzymes, such as catalase and MnSOD, are negatively regulated in various cancer cells, including prostate cancer, other redox enzymes or nonenzymatic antioxidant molecules participate in antioxidant defense of cancer cells. ${ }^{7,42}$ Therefore, not only are oxidants important in cancer progression, but cellular antioxidant defense systems may also be crucial in understanding the mechanism of malignant cancer generation. Activities of glutathione peroxidase, glutathione reductase, thioredoxin reductase, and glutathione-S-transferase are significantly higher in PC-3 cells than in LNCaP cells. ${ }^{43}$ Thus, in order to control tumor growth and decrease the number of surviving cells, a single therapeutic agent will likely not be sufficient, suggesting a need for combination therapies aimed at greater control of tumorigenesis.

Deregulation of Bcl-2 family members is often implicated in acquisition of resistance to apoptosis in malignant cell lines. Studies have shown that the expression of antiapoptotic proteins (Bcl-2, Bcl-xL, and Mcl-1) increases during prostate cancer progression. ${ }^{44}$ Increased Bcl-2 expression is associated with progression of prostate cancer from androgen-responsive to androgen-independent or hormone refractory disease. ${ }^{45}$ Therapeutic measures to decrease levels of Bcl-2 include delaying progression of prostate cancer in xenograft models to a state of androgen independence and enhancing chemosensitivity. ${ }^{46,47}$ Overexpression of $\mathrm{Bcl}-2$ protects $\mathrm{LNCaP}$ cells from apoptosis in vitro and in vivo. ${ }^{48}$ Finally, immunohistochemical analysis of Bcl-2 protein levels in prostate tumors has shown a correlation between the presence of $\mathrm{Bcl}-2$ protein and resistance to antiandrogen therapy. ${ }^{45} \mathrm{Mcl}-1$ expression also plays a key role in prostate cancer cell survival, suggesting that this gene may be involved in prostate carcinogenesis. While studies show that apoptosis is rapidly triggered in leukemia cells by antisense oligonucleotidemediated depletion of Mcl-1, other authors have shown that overexpression of Mcl-1 protects cells from apoptosis induced by actinomycin D. ${ }^{49,50}$ Our data demonstrate that apoptosis resulting from combination treatment with $2.5 \mu \mathrm{M}$ selenite and $20 \mu \mathrm{M}$ carmustine correlates with a shift in the balance of Bcl-2 and Mcl-1 protein expression from prosurvival to proapoptotic.

One of the biochemical landmarks of apoptosis is the formation of DNA double-stranded breaks. An early cellular response to DNA double-stranded breaks is the rapid phosphorylation of H2AX on Ser139 at sites of DNA damage. ROS-mediated DNA damage has long been thought to play a key role in carcinogenesis and malignant transformation; for example, hydroxyl radicals react with pyrimidines, purines, and chromatin protein, leading to base modifications, genomic instability, and alterations in gene expression. ${ }^{51}$ Consistent with our results, other studies have shown that selenite-induced apoptosis involves rapid induction of DNA single-strand and double-strand breaks in a variety of cells. ${ }^{8,22,52}$ PARP is important for the maintenance of DNA integrity. In our study, we observed increased DNA doublestranded breaks and cleavage of PARP with $2.5 \mu \mathrm{M}$ selenite treatment in $20 \mu \mathrm{M}$ carmustine-sensitized AIPC cells, which correlated with downregulation of Bcl-2 and Mcl-1 protein expression. Consistent with our findings, other studies have shown that inactivation of PARP by a dominant-negative 
mutation facilitates DNA fragmentation and rapid induction of apoptosis induced by alkylating agents and gamma radiation. ${ }^{53}$

In conclusion, our study demonstrated that nontoxic doses of selenite induced a substantial increase in apoptosis and growth inhibition in carmustine-sensitized AIPC cells, while preventing undesirable genotoxicity in normal prostate cells. The dual functions of carmustine (alkylation and carbamylation), in combination with selenite treatment, highlights the central role of these compounds in apoptosis of AIPC. Our data suggest that combined treatment with carmustine and selenite may provide a reasonable alternative to current therapeutic options and possess greater potential for treating patients suffering from AIPC. On the basis of these profound results, further preclinical studies (in vitro and in vivo) are warranted to establish the most effective concentrations of selenite and carmustine, to document tumor regression, and to rule out genotoxicity at therapeutically relevant dosages and treatment durations. The results from this study will not only benefit patients with prostate cancer, but can also be used in clinical situations involving several other cancers that are sensitive to high doses of selenite.

\section{Acknowledgments}

This study was supported by a grant from Henry Ford Health System (A10115). This work was presented in part at the Annual Meeting of the American Urological Association, May 29-June 3, 2010, San Francisco, CA [J Urol. 2010;183(Suppl 4):e461].

\section{Disclosure}

The authors declared no potential conflicts of interest.

\section{References}

1. Jin JK, Dayyani F, Gallick GE. Steps in prostate cancer progression that lead to bone metastasis. Int J Cancer. 2011;128(11):2545-2561.

2. American Cancer Society. Cancer Facts and Figures 2012. Atlanta, GA: American Cancer Society; 2012.

3. Mimeault M, Johansson SL, Vankatraman G, et al. Combined targeting of epidermal growth factor receptor and hedgehog signaling by gefitinib and cyclopamine cooperatively improves the cytotoxic effects of docetaxel on metastatic prostate cancer cells. Mol Cancer Ther. 2007;6(3):967-978.

4. Valko M, Leibfritz D, Moncol J, Cronin MT, Mazur M, Telser J. Free radicals and antioxidants in normal physiological functions and human disease. The international journal of biochemistry and cell biology. 2007;39(1):44-84.

5. Das U. A radical approach to cancer. Med Sci Monit. 2002;8(4): RA79-RA92.

6. Pelicano H, Carney D, Huang P. ROS stress in cancer cells and therapeutic implications. Drug Resist Updat. 2004;7(2):97-110.

7. Sun Y. Free radicals, antioxidant enzymes, and carcinogenesis. Free Radic Biol Med. 1990;8(6):583-599.
8. Ramoutar RR, Brumaghim JL. Antioxidant and anticancer properties and mechanisms of inorganic selenium, oxo-sulfur, and oxo-selenium compounds. Cell Biochem Biophys. 2010;58(1):1-23.

9. Lippman SM, Klein EA, Goodman PJ, et al. Effect of selenium and vitamin $\mathrm{E}$ on risk of prostate cancer and other cancers: the Selenium and Vitamin E Cancer Prevention Trial (SELECT). JAMA. 2009;301(1):39-51.

10. Zeng H, Combs GF Jr. Selenium as an anticancer nutrient: roles in cell proliferation and tumor cell invasion. J Nutr Biochem. 2008; 19(1):1-7.

11. Muecke R, Schomburg L, Buentzel J, Kisters K, Micke O. Selenium or no selenium - that is the question in tumor patients: a new controversy. Integr Cancer Ther. 2010;9(2):136-141.

12. Institute of Medicine. Panel of Dietary antioxidants and related compounds. Dietary reference intakes for vitamin C, Vitamin E, Selenium, and Carotenoids. A report of the panel on Dietary Antioxidants and Related Compounds. Food and Nutrition Board, Institute of Medicine. Washington, District of Columbia: National Academy Press; 2000.

13. Xiang N, Zhao R, Zhong W. Sodium selenite induces apoptosis by generation of superoxide via the mitochondrial-dependent pathway in human prostate cancer cells. Cancer Chemotherapy and Pharmacology. 2009;63(2):351-362.

14. Husbeck B, Peehl DM, Knox SJ. Redox modulation of human prostate carcinoma cells by selenite increases radiation-induced cell killing. Free Radic Biol Med. 2005;38(1):50-57.

15. Kandas NO, Randolph C, Bosland MC. Differential effects of selenium on benign and malignant prostate epithelial cells: stimulation of $\mathrm{LNCaP}$ cell growth by noncytotoxic, low selenite concentrations. Nutr Cancer. 2009;61(2):251-264.

16. Morrison DG, Medina D. Distinguishing features of cytotoxic and pharmacological effects of selenite in murine mammary epithelial cells in vitro. Toxicol Lett. 1988;44(3):307-314.

17. Shen HM, Yang CF, Ding WX, Liu J, Ong CN. Superoxide radicalinitiated apoptotic signalling pathway in selenite-treated HepG(2) cells: mitochondria serve as the main target. Free Radic Biol Med. 2001;30(1):9-21.

18. Kim YS, Jhon DY, Lee KY. Involvement of ROS and JNK1 in selenite-induced apoptosis in Chang liver cells. Exp Mol Med. 2004;36(2):157-164.

19. Gallo M, Aragno M, Gatto V, et al. Protective effect of dehydroepiandrosterone against lipid peroxidation in a human liver cell line. Eur J Endocrinol. 1999;141(1):35-39.

20. Corcoran NM, Najdovska M, Costello AJ. Inorganic selenium retards progression of experimental hormone refractory prostate cancer. J Urol. 2004;171(2 Pt 1):907-910.

21. Tian J, Ning S, Knox SJ. Sodium selenite radiosensitizes hormonerefractory prostate cancer xenograft tumors but not intestinal crypt cells in vivo. Int J Radiat Oncol Biol Phys. 2010;78(1):230-236.

22. Li GX, Lee HJ, Wang Z, et al. Superior in vivo inhibitory efficacy of methylseleninic acid against human prostate cancer over selenomethionine or selenite. Carcinogenesis. 2008;29(5):1005-1012.

23. Davis MR, Kassahun K, Jochheim CM, Brandt KM, Baillie TA. Glutathione and $\mathrm{N}$-acetylcysteine conjugates of 2-chloroethyl isocyanate. Identification as metabolites of $\mathrm{N}, \mathrm{N}^{\prime}$-bis(2-chloroethyl)-N-nitrosourea in the rat and inhibitory properties toward glutathione reductase in vitro. Chem Res Toxicol. 1993;6(3):376-383.

24. Thamilselvan V, Menon M, Thamilselvan S. Anticancer efficacy of deguelin in human prostate cancer cells targeting glycogen synthase kinase-3 beta/beta-catenin pathway. Int J Cancer. 2011;129(12):2916-2927.

25. Rashed T, Menon M, Thamilselvan S. Molecular mechanism of oxalate-induced free radical production and glutathione redox imbalance in renal epithelial cells: effect of antioxidants. Am J Nephrol. 2004;24(5):557-568.

26. Thamilselvan V, Menon M, Thamilselvan S. Oxalate-induced activation of PKC-alpha and -delta regulates NADPH oxidase-mediated oxidative injury in renal tubular epithelial cells. Am J Physiol Renal Physiol. 2009;297(5):F1399-F1410. 
27. Shack S, Miller A, Liu L, Prasanna P, Thibault A, Samid D. Vulnerability of multidrug-resistant tumor cells to the aromatic fatty acids phenylacetate and phenylbutyrate. Clin Cancer Res. 1996;2(5):865-872.

28. Batist G, Katki AG, Klecker RW Jr, Myers CE. Selenium-induced cytotoxicity of human leukemia cells: interaction with reduced glutathione. Cancer Res. 1986;46(11):5482-5485.

29. Jiang C, Hu H, Malewicz B, Wang Z, Lu J. Selenite-induced p53 Ser15 phosphorylation and caspase-mediated apoptosis in LNCaP human prostate cancer cells. Mol Cancer Ther. 2004;3(7):877-884.

30. Menter DG, Sabichi AL, Lippman SM. Selenium effects on prostate cell growth. Cancer Epidemiol Biomarkers Prev. 2000;9(11):1171-1182.

31. Shen HM, Yang CF, Ong CN. Sodium selenite-induced oxidative stress and apoptosis in human hepatoma HepG2 cells. Int J Cancer. 1999;81(5):820-828.

32. Zhong W, Yan T, Webber MM, Oberley TD. Alteration of cellular phenotype and responses to oxidative stress by manganese superoxide dismutase and a superoxide dismutase mimic in RWPE-2 human prostate adenocarcinoma cells. Antioxid Redox Signal. 2004;6(3):513-522.

33. Seko Y, Saito Y, Kitahara J, Imura N. Active oxygen generation by the reaction of selenite with reduced glutathione in vitro. In: Wendel A, editor. Selenium in Biology and Medicine. Berlin, Germany: SpringerVerlag; 1989.

34. Combs GF Jr, Gray WP. Chemopreventive agents: selenium. Pharmacol Ther. 1998;79(3):179-192.

35. Husbeck B, Nonn L, Peehl DM, Knox SJ. Tumor-selective killing by selenite in patient-matched pairs of normal and malignant prostate cells. Prostate. 2006;66(2):218-225.

36. Shen H, Yang C, Liu J, Ong C. Dual role of glutathione in seleniteinduced oxidative stress and apoptosis in human hepatoma cells. Free Radic Biol Med. 2000;28(7):1115-1124.

37. Zhang K, Mack P, Wong KP. Glutathione-related mechanisms in cellular resistance to anticancer drugs. Int J Oncol. 1998;12(4):871-882.

38. Ali-Osman F, Stein DE, Renwick A. Glutathione content and glutathione-S-transferase expression in 1,3-bis(2-chloroethyl)-1nitrosourea-resistant human malignant astrocytoma cell lines. Cancer Res. 1990;50(21):6976-6980.

39. Ali-Osman F, Antoun G, Wang H, Rajagopal S, Gagucas E. Buthionine sulfoximine induction of gamma-L-glutamyl-L-cysteine synthetase gene expression, kinetics of glutathione depletion and resynthesis, and modulation of carmustine-induced DNA-DNA cross-linking and cytotoxicity in human glioma cells. Mol Pharmacol. 1996;49(6):1012-1020.

40. LeBoeuf RA, Hoekstra WG. Adaptive changes in hepatic glutathione metabolism in response to excess selenium in rats. $J$ Nutr. 1983;113(4): $845-854$
41. LeBoeuf RA, Laishes BA, Hoekstra WG. Effects of selenium on cell proliferation in rat liver and mammalian cells as indicated by cytokinetic and biochemical analysis. Cancer Res. 1985;45(11 Pt 1):5496-5504.

42. Bostwick DG, Alexander EE, Singh R, et al. Antioxidant enzyme expression and reactive oxygen species damage in prostatic intraepithelial neoplasia and cancer. Cancer. 2000;89(1):123-134.

43. Lim HW, Hong S, Jin W, et al. Up-regulation of defense enzymes is responsible for low reactive oxygen species in malignant prostate cancer cells. Exp Mol Med. 2005;37(5):497-506

44. Krajewski S, Chatten J, Hanada M, Reed JC. Immunohistochemical analysis of the $\mathrm{Bcl}-2$ oncoprotein in human neuroblastomas. Comparisons with tumor cell differentiation and N-Myc protein. Lab Invest. 1995;72(1): 42-54.

45. McDonnell TJ, Troncoso P, Brisbay SM, et al. Expression of the protooncogene bcl-2 in the prostate and its association with emergence of androgen-independent prostate cancer. Cancer Res. 1992;52(24): 6940-6944.

46. Miyake H, Tolcher A, Gleave ME. Antisense Bcl-2 oligodeoxynucleotides inhibit progression to androgen-independence after castration in the Shionogi tumor model. Cancer Res. 1999;59(16):4030-4034.

47. Gleave ME, Miayake H, Goldie J, Nelson C, Tolcher A. Targeting bcl-2 gene to delay androgen-independent progression and enhance chemosensitivity in prostate cancer using antisense bcl-2 oligodeoxynucleotides. Urology. 1999;54(Suppl 6A):36-46.

48. Raffo AJ, Perlman H, Chen MW, Day ML, Streitman JS, Buttyan R. Overexpression of bcl-2 protects prostate cancer cells from apoptosis in vitro and confers resistance to androgen depletion in vivo. Cancer Res. 1995;55(19):4438-4445.

49. Moulding DA, Giles RV, Spiller DG, White MR, Tidd DM, Edwards SW. Apoptosis is rapidly triggered by antisense depletion of MCL-1 in differentiating U937 cells. Blood. 2000;96(5):1756-1763.

50. Zhang B, Gojo I, Fenton RG. Myeloid cell factor-1 is a critical survival factor for multiple myeloma. Blood. 2002;99(6):1885-1893.

51. Toyokuni S, Okamoto K, Yodoi J, Hiai H. Persistent oxidative stress in cancer. FEBS Lett. 1995;358(1):1-3.

52. Toyokuni S, Sagripanti JL, Hitchins VM. Cytotoxic and mutagenic effects of ferric nitrilotriacetate on L5178Y mouse lymphoma cells. Cancer Lett. 1995;88(2):157-162.

53. Beneke R, Geisen C, Zevnik B, et al. DNA excision repair and DNA damage-induced apoptosis are linked to poly(ADP-ribosyl) ation but have different requirements for p53. Mol Cell Biol. 2000;20(18):6695-6703.
Cancer Management and Research

\section{Publish your work in this journal}

Cancer Management and Research is an international, peer-reviewed open access journal focusing on cancer research and the optimal use of preventative and integrated treatment interventions to achieve improved outcomes, enhanced survival and quality of life for the cancer patient The journal welcomes original research, clinical \& epidemiological

\section{Dovepress}

studies, reviews \& evaluations, guidelines, expert opinion \& commentary, case reports \& extended reports. The manuscript management system is completely online and includes a very quick and fair peerreview system, which is all easy to use. Visit http://www.dovepress.com/ testimonials.php to read real quotes from published authors. 